$10-2012$

\title{
Pervasive Inequality in the Stratification of Four-Year College Destinations
}

Mark Engberg

Loyola University Chicago, mengber@luc.edu

Follow this and additional works at: https://ecommons.luc.edu/education_facpubs

Part of the Education Commons

\section{Author Manuscript}

This is a pre-publication author manuscript of the final, published article.

\section{Recommended Citation}

Mark E. Engberg (2012): Pervasive Inequality in the Stratification of Four-Year College Destinations, Equity \& Excellence in Education, 45:4, 575-595

This Article is brought to you for free and open access by the Faculty Publications and Other Works by Department at Loyola eCommons. It has been accepted for inclusion in Education: School of Education Faculty Publications and Other Works by an authorized administrator of Loyola eCommons. For more information, please contact ecommons@luc.edu.

\section{cc) (†) $\ominus$}

This work is licensed under a Creative Commons Attribution-Noncommercial-No Derivative Works 3.0 License. (c) 2012 University of Massachusetts Amherst School of Education 


\title{
PERVASIVE INEQUALITY IN THE STRATIFICATION OF FOUR-YEAR COLLEGE
}

\section{DESTINATIONS}

\author{
Mark E. Engberg \\ Loyola University Chicago
}

\begin{abstract}
Rooted in sociological models of educational transitions and tracking, this study examines patterns of stratification in the educational trajectories of low- and high-socioeconomic students. Utilizing longitudinal data from the Educational Longitudinal Study of 2002, this study describes qualitative differences in students' choice sets based on a number of metrics obtained from the Integrated Postsecondary Data System (IPEDS). Additionally, multinomial logistic regression models are used to demonstrate the relative probabilities of attending a low, moderate, or highselectivity undergraduate institution between students of low and high-socioeconomic statuses. Overall, the results demonstrate the pervasiveness of inequality in the college choice decisions of low- and high-SES students and the continued stratification of opportunity for students based on their family background. The study concludes with implications for policymakers and practitioners working within secondary and postsecondary educational sectors.
\end{abstract}

Educational access, particularly as it relates to postsecondary education, remains a critical social justice concern of the $21^{\text {st }}$ century. While numerous technical reports point to the opening of opportunity for all groups (NCES, 2007) and the concomitant attenuation of educational inequality (Arum, Gamoran, \& Shavit, 2007), few studies have examined how more qualitative forms of stratification (e.g., selectivity of institutions) pervade the college choice process, especially among those students who go on to four-year institutions. Rather, most studies have 
highlighted how social origins and access to capital manifest in the unequal distribution of lowincome and underrepresented racial/ethnic minority students within different hierarchical tracks (i.e., two-year versus four-year; Arum et al., 2007; Engberg \& Allen, 2011; Perna \& Titus, 2005).

The expansion of higher education, however, has led to a graduation erosion of the value of a college degree (i.e., a baccalaureate degree no longer ensures a good job for all; Arum et al., 2007), placing an overall higher premium on qualitative differences in degree attainment. Research has demonstrated the benefits of attending a more prestigious college or university, particularly as it relates to labor market outcomes (Brewer, Eide, \& Ehrenberg, 1999; Thomas, 2000) and social mobility (Breen \& Jonsson, 2000). Other researchers have argued that the general expansion of higher education has led to a more differentiated and stratified system that continues to protect those institutions that enroll students of higher socioeconomic means (Thomas \& Perna, 2004).

The mechanisms that drive stratification in higher education have been explored through a number of different paradigms and institutional perspectives. Economic theories point to differences in access to information when determining the benefits and costs of attending college, whereas sociological theories highlight status attainment and access to social networks (Perna, 2006). These theoretical paradigms, however, have been largely employed to understand enrollment decisions that often overlook qualitative differences within different educational stratum, particularly four-year institutions. Other researchers have implicated the enrollment management strategies used by four-year institutions, such as the types of high schools visited during fall recruitment, which has resulted in feeder patterns that privilege wealthier and primarily white students (Wolniak \& Engberg, 2007). In addition, researchers have emphasized 
the organizational habitus of the high school (e.g., organizational norms and structures), particularly the role of guidance counselors, as a significant force in shaping and delimiting the opportunity structure for students of different socioeconomic means (McDonough, 1997).

Among the various sociological theories that have emerged to explain educational inequality, Lucas's (2001) theory of Effectively Maintained Inequality provides a compelling rationale for the pervasiveness of inequality that counters many of the shortcomings of competing approaches. In particular, Lucas's approach recognizes that within a rapidly expanding educational system, such as the current postsecondary sector, inequality as it relates to overall attendance is eventually replaced by more qualitative forms of inequality in relation to who has access to more selective forms of education. While Lucas has demonstrated the pervasiveness of inequality in the educational transitions of high school students from lower and higher socioeconomic statuses, his research fell short in demonstrating the more qualitative component of his argument as it relates to postsecondary institutions. In recognizing this limitation of his work, Lucas suggests that more research is needed that explores patterns of inequality across the postsecondary selectivity spectrum.

The purpose of this study is to demonstrate the extent to which socioeconomic status delimits educational opportunity among students who attend a four-year institution. In using data from the Educational Longitudinal Study of 2002 in conjunction with a recognized classification system of four-year selectivity (i.e., Carnegie Classification), I demonstrate the pervasiveness of inequality as it relates to the selectivity of four-year college destinations. I begin my analyses by investigating qualitative differences throughout the college choice process, including an examination of the schools that students applied to, were admitted to, and enrolled at immediately upon high school graduation. In adhering to Lucas's (2001) contention that such 
research must also demonstrate that the relative probabilities between students from the lowest and highest socioeconomic stratum are distinctly different, I apply a similar segmentation that pays particular attention to the probability of a student attending a low-, moderate-, or highselectivity school within different academic quartiles.

This study adds to the extant research on institutional stratification in a number of ways. First, this is one of the only studies to date to analyze the complete choice sets of a nationally representative sample of students, providing a more nuanced understanding of not only enrollment differences but also the compositional differences in the applicant and admitted choice sets of these students. In this way, I provide more transparency to scholars and policymakers who are interested in understanding the pervasiveness of stratification throughout the college choice process. Second, I compare the results for students in the highest and lowest socioeconomic strata within differing levels of academic preparation. As such, the differences show the degree of stratification within similar levels of academic preparation, which is often considered the most influential sorting mechanism in relation to institutional selectivity (Bastedo \& Jaquette, 2011). Finally, the results provide direction in thinking about policies and practices that may potentially level the playing field and improve the opportunity structure for students from lower socioeconomic backgrounds.

\section{LITERATURE REVIEW AND CONCEPTUAL FRAMEWORK}

I used three different literature sources to frame the study. First, I review the sociological literature as it relates to stratification in schooling, with a particular focus on Lucas's (2001) theory of Effectively Maintained Inequality. Next, I provide information about the models used to describe the college choice process, highlighting the major theoretical paradigms used to describe disparities in college access. I then review the literature on college selectivity, exploring 
those studies that have examined the benefits of selectivity in relation to completion and labor market outcomes. Finally, I discuss the prevailing hypotheses used to explain disparities between low- and high-SES students in relation to their academic preparation and institutional selectivity. Effectively-Maintained Inequality

Sociologists have a long history of studying educational transitions, particularly the effects of socioeconomic status on secondary and postsecondary educational attainment. Research has generally shown that the effects of family background diminish over time (Shavit \& Blossfeld, 1993), although the rationale behind this pattern of effects has been addressed through different theoretical perspectives. The Life Course Perspective (Müller \& Karle, 1993), for instance, posits that the diminished effects of family background are a result of the growing independence between child and parent during later educational transitions. The theory of Maximally Maintained Inequality (MMI) (Raftery \& Hout, 1993), however, hypothesizes that the effects of family background only diminish when educational attainment becomes compulsory and near universal, such as in secondary education, and further expansion cannot be maintained by students in the highest socioeconomic stratum. More importantly, though, MMI postulates that the effects of socioeconomic status are contingent on the socio-political context in which education occurs; in other words, if education policy dictates a change in the relative importance of a particular transition, the effects of social origin may become more or less important in later educational transitions.

While both of these theories are important in understanding the role of socioeconomics in educational transitions, they overlook how such transitions often incorporate qualitative differences in the types of experiences afforded to students of varying socioeconomic means. Lucas (2001), for instance, argues that educational tracking remains an important consideration 
in understanding educational transitions, as students' access to qualitatively different types of educational experiences (i.e., particular courses) is often dependent on their social background, particularly as the role of school counselors has diminished over time (Rosenbaum, Miller, \& Krei, 1996). Research on parent involvement also shows a clear relationship to postsecondary access (Perna \& Titus, 2005), suggesting that parents play a critical role not only in relation to their children's decisions to attend college but also regarding the types of experiences they are encouraged to pursue along the way.

The theory of Effectively Maintained Inequality (Lucas, 2001) draws upon prior sociological work in both educational transitions and tracking and posits that dominant groups will act to preserve their positions in society by actively pursuing both quantitatively and qualitatively better forms of education. As education becomes more universal, parents from higher socioeconomic strata will "seek out whatever qualitative differences there are at that level and use their advantages to secure quantitatively similar but qualitatively better education" ( $\mathrm{p}$. 1652). Lucas's findings demonstrate that socioeconomic indicators are important even when education becomes nearly universal at a particular level and that the effects are particularly relevant in predicting qualitative differences in the types of educational opportunities afforded to advantaged students. The present study builds on Lucas's prior work by examining qualitative differences in the choice sets and enrollment destinations of a group of students who successfully enrolled in a four-year college after high school graduation. Thus, the focus of this study is not on the educational transition to college, which has been studied extensively, but rather is a closer examination of the ways in which socioeconomic status influences college choice considerations at the applicant, admit, and enrollment stages, taking into account students' varying levels of academic preparation. 


\section{Models of College Choice}

The college choice process has been aptly described as a three-stage process that begins with one's predispositions toward attending college, followed by a search stage in which information is gathered about specific institutional options, and concluding with a choice stage in which applications are submitted and enrollment decisions are made (Hossler \& Gallagher, 1987;

Hossler, Schmit, \& Vesper, 1999). Many of these choices are circumscribed by students' socioeconomic background, including their access to different forms of capital (i.e., economic, human, social, and cultural) that invariably leads to more developed social networks that provide greater access to knowledge and information about the college choice process (Engberg \& Wolniak, 2010; Perna, 2006).

From an economic perspective, human capital theory grounds the decision to attend college in the language of productivity-enhancement and investment returns (Becker, 1993; Paulsen, 2001). Calculating the economic returns from an investment in postsecondary education, however, requires access to accurate information, and research has shown that lowincome students are comparatively disadvantaged in their acquisition of knowledge about postsecondary education (Cabrera \& La Nasa, 2001). A number of economic considerations related to the cost of attendance (e.g., price, grant aid) have also been linked to college enrollment, with higher costs often diminishing low-income students' propensities to attend college (Leslie \& Brinkman, 1987; Paulsen, 2001). Ellwood and Kane (2000), for instance, found significant enrollment disparities between students from the lowest and highest income quartiles even when controlling for equivalent levels of academic preparation.

From a sociological perspective, students' pathways to college exist within more general models of status attainment and social mobility (e.g., Grodsky, 2007; Karen, 1990; Lucas, 2001; 
Rosenbaum, 1978; Turner, 1960). Educational achievement and social ties partially determine the levels of social capital accessible to students, which in turn provides assistance in obtaining additional education and making effective educational choices (Coleman, 1988; Lin, 1999). Research shows the importance of different social networks in increasing the likelihood of college attendance, with particular attention to parent, peer, and other college-linking networks (Engberg \& Allen, 2011; Engberg \& Wolniak, 2010; Hill, 2008; Pérez \& McDonough, 2008; Perna \& Titus, 2005). Disparities, however, exist in relation to students' access to different social networks, and studies show that economically advantaged students have greater access to private counselors (McDonough, 1994), take college entrance examinations more frequently (Fitzgerald \& Delaney, 2002), and attend high schools with more established college feeder relationships (Wolniak \& Engberg, 2007).

\section{Institutional Selectivity: Disparities and Benefits}

While the majority of research on college access has focused on who goes to college, a number of studies have more closely examined patterns of institutional selectivity across socioeconomic strata. Carnevale and Rose (2003) found that a student from a wealthy family is approximately 25 times more likely to attend a highly selective institution than students from lower income families. When examining students who attend the top 146 schools in the nation, only $10 \%$ of those students came from the bottom socioeconomic quartile (Carnevale \& Rose, 2003). Findings from the Educational Trust reveal similar disparities in relation to the nation's flagship institutions, with only $13 \%$ of students from low income families attending a public flagship (compared to a population with over $20 \%$ of low-income families) (Haycock, Lynch, \& Engle, 2010); this finding is especially alarming, given the public mission of these institutions to educate students from working-class backgrounds. 
These disparities become more meaningful when examining the benefits that accrue to students who attend highly selective postsecondary institutions. Selective institutions, for instance, expend considerably more money per student, graduate students at a substantially higher rate, and have more students go on to graduate school (Carnevale, 2010). As a result, graduates of highly selective schools earn, on average, $45 \%$ more in an entry level job compared to graduates of less selective institutions (Carnevale, 2010). More recently, researchers uncovered a positive correlation between institutional selectivity and indicators of student development and critical thinking (Arum, Roksa, \& Cho, 2011).

\section{Fit, Mismatch, and Undermatching Hypotheses}

Given both the disparities in selective school access among low- and high-socioeconomic backgrounds and the concomitant benefits that derive from graduating from an elite university, a number of scholars have proposed hypotheses to address the benefits and causes of institutional stratification. Many of these theories were initially derived from research on race-based admission policies (e.g., affirmative action policies) and later expanded to examine socioeconomic differences. The "fit hypothesis," for instance, originated out of research related to affirmative action policies and addresses whether African American students would graduate at higher rates if they attended an institution that had a higher academic profile (i.e., standardized test scores) than their individual academic profile (Bowen \& Bok, 1998). The researchers concluded that the fit hypothesis did not hold true and African American students with the lowest SAT scores actually graduated at a higher rate than similar students attending less selective institutions (Bowen \& Bok, 1998). Alon and Tienda (2005) coined a similar term, the "mismatch" hypothesis, to explain whether racial/ethnic minority students who attended college during the 1980s and 1990s would have achieved similar benefits if they attended a higher 
academic profile institution compared to their individual academic profiles. Similar findings were revealed from this study, with higher graduation rates significantly related to increased levels of selectivity, and higher benefits derived for minority students in relation to white students.

More recently, Bowen, Chingos, and McPherson (2009) proposed the "undermatching" hypotheses, which examines whether students from lower socioeconomic backgrounds are attending colleges that are less selective than their academic preparation would warrant. Their results reveal that a large proportion of low-income students were attending less selective institutions despite having academic credentials consonant with more selective institutions. A new study by Bastedo and Jaquette (2011) examined the "undermatching" hypothesis over time and concluded that even though low-income students have made substantial gains in their academic achievements over time, wealthier students have made even bigger gains, such that even if low-income students were perfectly matched to institutions based on their academic credentials, high levels of stratification would still remain across socioeconomic strata. This phenomenon, which the authors coined "running in place" (p. 318) demonstrates that highincome students have outpaced their low-income counterparts in relation to their performance on both test scores and coursework, which has concomitantly provided high-income students with a competitive advantage in the marketplace for selective colleges and universities.

The confluence of these perspectives on inequality and educational attainment suggests the predominant role of socioeconomic status in both the decision to attend college and the type of college one chooses to attend. The present study continues this line of inquiry by examining patterns of stratification at all stages of the college choice process, with particular attention to 
strata related to academic preparation, socioeconomic status (SES), and institutional selectivity. In particular, the study addresses the following two research questions:

1. Among low- and high-SES students of varying levels of academic preparation, are there qualitative differences in the institutional characteristics of the schools they apply to, are admitted to, and enroll in immediately upon high school graduation?

2. Among low- and high-SES students of varying levels of academic preparation, are there significant differences in their enrollment propensities based on institutional selectivity?

\section{METHODS}

\section{Data and Sample}

For this study, I used data collected through the Education Longitudinal Study (ELS) of 2002, a survey research project funded by the U.S. Department of Education designed to explore students' transitions from secondary school into postsecondary education and the workforce. The ELS study is both longitudinal, surveying the same group of students over time, and multi-level, collecting information from multiple respondent pools that include students, parents, teachers, librarians, and school principals. The analytic sample for this study is based on the 2004 panel of students who were seniors in high school and indicated on the second follow-up in 2006 that they had attended a non-profit, public or private, four-year institution immediately upon graduation (i.e., continuously enrolled). By selecting a sample of continuously enrolled students, I was able to mitigate differences in students' choice sets due to the timing of college matriculation, while allowing for a more comprehensive examination of institutional characteristics reported most frequently among non-profit, four-year institutions. The weighted sample included 1,193,611 students with the following demographic characteristics: $56 \%$ female, $71 \%$ White, $11 \%$ Black, $7 \%$ Hispanic, $6 \%$ Asian, and 5\% unknown racial classifications ${ }^{1}$. 


\section{Variables}

The dependent variable in this study was a multinomial variable that represented three increasing levels of selectivity based on the Carnegie Classification of 2005 (Carnegie Foundation, n.d.): inclusive, moderate-, and high-selectivity. ${ }^{2}$ The Carnegie Classification is based on the entering standardized test scores of students (i.e., converted SAT and ACT scores) at the $25^{\text {th }}$ percentile level, which corresponds to an ACT equivalent of less than $18,18-21$, and greater than 21 for the inclusive, moderate, and high-selectivity categories, respectively. The Carnegie Classification places schools that were test optional in 2005 and did not report standardized scores in the inclusive category and presumes these are institutions with few admissions requirements and lower $25^{\text {th }}$ percentile scores.

The ELS data set is unique in that the complete college choice sets are provided for all students, including the colleges that students applied to, were admitted to, and attended immediately after high school graduation. To better understand the institutional characteristics of students' choice sets at each stage of the college decision-making process, I incorporated a number of different metrics available in the Integrated Postsecondary Data Set (IPEDS). As students matriculated during the 2004-2005 year, I used corresponding IPEDS information from the same academic year, with the exception of certain data elements that were only available in a subsequent year ${ }^{3}$. Institutional characteristics included the following: public versus private sector; cost of attendance for out-of-state students ${ }^{4}$; standardized test scores; first-year retention rates; six-year graduation rates, fully-loaded cost of instruction per full time equivalent (FTE); and endowment per FTE. Standardized test scores were based on the $50^{\text {th }}$ percentile of entering students' SAT or converted ACT scores, using a weighted average based on the proportion of SAT and ACT test-takers at a particular college. The fully-loaded cost of instruction was based 
on the total expenditures per FTE reported for instruction, academic support services, and student services. Averages for each of the institutional characteristics were calculated across the total number of schools a student applied to or was admitted to; the enrollment destinations were based on the first school that a student continuously enrolled in upon high school graduation and therefore exclude transfer students or those students who delayed their enrollment.

In addition to institutional characteristics, I used a number of covariates to assess students' socioeconomic status (SES), academic preparation, and demographic characteristics. The SES measure was based on the imputed, composite index in the ELS data set that includes information on family income, family educational attainment, and family occupational attainment. While scholars have debated the merits of using the composite index over the individual components, there are inherent tradeoffs based on either decision ${ }^{5}$. While the individual components provide a more nuanced understanding of the varied relationships among socioeconomic metrics, the components are highly correlated (Davis-Kean, 2005), which can create additional problems in multivariate analyses related to both multicollinearity and endogeneity effects. For the purposes of this study, I segmented the index into quartiles to examine socioeconomic differences among low- and high-SES students. The decision to use quartiles was based primarily on maintaining adequate sample sizes within each cell of the descriptive matrix while providing an efficient lens to understand socioeconomic and academic differences. Analyses using both the segmented and continuous indices provided similar results in all phases on the analyses.

For academic preparation, I created a composite index that incorporated three different metrics: incidence of Advanced Placement/International Baccalaureate tests, high school grade point average, and highest reported SAT or converted ACT score ${ }^{6}$. My selection of metrics was 
based on the results of a logistic regression equation, in which I selected those measures that shared a significant relationship with the likelihood of attending a highly selective school. ${ }^{7}$ Each of these measures was standardized and weighted according to their relative explanatory power in predicting the likelihood of attendance at a highly selective institution. The weighted scores were then averaged and the final composite index was segmented into quartiles. Table 1 presents the average scores for each of the academic metrics across the academic profile quartiles. Finally, I included two sets of covariates to control for students' gender and race. The race variable included five categories pertaining to White, Asian, Black, Hispanic, and Native American students as well as an additional category to represent students who identified with an alternative racial classification.

\section{$<<$ INSERT TABLE 1 HERE $>>$}

\section{Analytic Techniques}

To address the study's research questions, I employed a number of data conditioning steps to capture each of the schools that a student applied to, was admitted to, and enrolled in immediately after graduation. For each school in a students' choice set, I merged all of the IPEDS data listed above, restructured the data into a flat file ${ }^{8}$, and then either summed (in the case of the number of selective or public/private schools) or averaged the metrics to obtain an estimate for all of the schools that a student applied to or was admitted to during his or her senior year of high school. To identify students who were continuously enrolled in college, I examined the enrollment destinations of students over the two-year period following high school and only chose schools that students matriculated at immediately following high school graduation (or the preceding summer if they remained continuously enrolled). In doing so, the data allow for qualitative comparisons of choice sets and enrollment destinations, while controlling for 
differences based on students who delay, transfer, or stop-out within the first two years following high school graduation.

In addition to data conditioning, I employed two different analytic techniques to address the study's research questions. The first research question was designed to understand qualitative differences in the institutional characteristics that comprised a student's choice sets across SES and academic profile scores. I used an ANOVA with Tukey post-hoc tests to identify whether significant differences existed between low and high SES groups within each academic band across the full set of institutional characteristics that comprised a student's choice set at the applicant, admit, and enrollment stages. As the primary purpose of the study was to understand patterns of stratification, I only display the mean values and associated tests of significance for low- and high-SES students in each of the respective academic quartiles

The second research question required the use of multivariate techniques to understand whether there were significant differences in the probabilities of enrollment selectivity for lowand high-SES students across different levels of academic preparation. I initially used an ordinal regression technique with a logit function to examine the probabilities for each selectivity category ${ }^{9}$. However, the test of parallel lines was not met, suggesting that the coefficients were not constant across categories and indicating the use of a multinomial logistic method in which the low-selectivity group was used as the referent group. To understand the unique effects of academic preparation within each SES quartile, I ran separate multinomial regressions for each SES quartile and used the "prvalue" function in STATA to understand the cumulative probabilities across the three enrollment classifications, controlling for each respective level of academic preparation. Results are presented as 95\% confidence levels for the low- and high-SES groups within each academic preparation level; significant differences can easily be identified 
when the probabilities of a low-SES group fall outside the confidence levels of a high-SES group (or vice versa). With the exception of missing data on the academic index (approximately 6\%), the SES index and demographic covariates contain complete data for each of the respondents.

\section{Limitations}

There a number of limitations within the current study. First, the choice set information was gathered from students at the time of the second follow up (when they were completing their sophomore year of college). This required a fair amount of retrospective recall, particularly for those students who initially applied to a large number of schools. Despite this limitation, ELS (along with its predecessors) remains the only data set to capture the choice sets of students across a national sample of high school students. While data captured by the National Student Clearinghouse (NSC) provide an accurate understanding of enrollment destinations, the NSC does not capture information related to students' choice sets at the applicant or admitted stages of the choice process.

Additionally, IPEDS data, while a reporting requirement for schools receiving Title IV funding, are verified at the institutional level, and discrepancies and reporting errors are certainly possible. Further, while IPEDS data are consistently reported at the four-year level, many of the reporting categories do not apply to two-year and for-profit institutions, and the averages presented at the applicant and admit stages are largely reflective of the four-year averages. This limitation was most pronounced in the application choice sets when examining the lowest academic bands (8\%-15\% of the schools listed were not four-year, non-profit institutions) and least pronounced in the higher academic bands (approximately 4\%-8\% of the schools listed were not four-year, non-profit institutions). The results, however, are only shown in the aggregate 
across SES and academic groups, thereby minimizing the potential error in the reported estimates.

The use of the Carnegie Classification of selectivity is a relatively limited metric as it solely relies on standardized test scores and should not be interpreted as a proxy for institutional quality. I deliberatively examined student choice sets across a number of institutional characteristics, some of which relate to dimensions of institutional quality and wealth. The purpose of this study, however, is not to enter into the debate about appropriate metrics of institutional quality; rather, the purpose is to examine stratification patterns in the choice sets and enrollment destinations of a nationally representative group of high- and low-SES students. Further, while stratification is evident across different racial groups, a segmented analysis that examined both race and SES across academic preparation quartiles would require a larger sample, as many of the segmented cells would be too small to make accurate and reliable generalizations.

Finally, I used a parsimonious model to estimate the probabilities of enrollment, and this can potentially lead to an omitted variable bias. Alternative models were tested ${ }^{10}$, and each revealed similar findings and did little to improve the overall classification of students in the models. The model used in this study is less susceptible to multicollinearity and endogeneity threats compared to more omnibus models and was purposefully designed to address covariates related to academic preparation, socioeconomics, and demographic characteristics.

\section{RESULTS}

\section{Qualitative Differences}

To better understand patterns of stratification between low- and high-SES students in each of the academic quartiles, I ran ANOVA and Tukey post-hoc tests to examine group 
differences in the institutional characteristics associated with the schools that students applied to, were admitted to, and enrolled in immediately after high school. As shown in the bottom row of Table 2, the ANOVA F-tests revealed highly significant $(p<.001)$ between-group differences across all of the institutional characteristics under investigation. Based on these significant findings, I then ran Tukey post-hoc tests to understand whether there were significant differences between the low- and high-SES groups within each academic quartile. In examining the number of schools students applied to, which ranged from a low of 1 to a high of 18, high SES students applied to significantly more schools than low-SES students in the third and fourth academic quartiles $(M=3.98$ vs. $2.96, p<.001$ and $M=4.48$ vs. $3.87, p<.05$ respectively); nonsignificant differences $(\mathrm{p}>.05)$ were found in the first and second quartiles.

Significant differences $(p<.001)$ were also discovered between high- and low-SES students in relation to the percentage of inclusive, moderate-, and high-selectivity schools included in their applicant choice sets. Low-SES students, for instance, reported a significantly higher percentage of inclusive schools compared to their high-SES counterparts in the first and second academic bands $(M=28.5 \%$ vs. $10.8 \%, p<.001$ and $M=11.0 \%$ vs. $3.7 \%, p<.001$ respectively). The opposite pattern was found in relation to moderately selective schools, with low-SES students associated with a significantly higher percentage of moderate schools in the third and fourth academic bands compared to their high-SES counterparts $(M=52.0 \%$ vs. $37.9 \%$, $p<.001$ and $M=35.7 \%$ vs. $16.8 \%, p<.001$, respectively). Compared to low-SES students, high-SES students applied to a significantly greater $(p<.001)$ percentage of highly selective schools in each of the academic quartiles. In the lowest academic quartile, the proportion of highly selective schools was two and half times greater for high-SES students compared to lowSES students $(M=22.0 \%$ vs. $M=8.8 \%, p<.001$, respectively). 


\section{$<<$ INSERT TABLE 2 HERE $>>$}

In relation to the mix of public and private schools, high-SES students applied to a significantly higher percentage of private schools than low-SES students in the second and fourth academic groups $(M=29.1 .0 \%$ vs. $16.5 \%, p<.001$ and $M=51.9 \%$ vs. $34.8 \%, p<.001$, respectively); the opposite trend was found among the public schools. Given these trends, it was not surprising to find that the average cost of attendance was significantly higher for high-SES students compared to their low-SES counterparts in academic groups two $(M=\$ 23,906$ vs. $\$ 26,006, p<.001)$, three $(M=\$ 25,934$ vs. $\$ 27,944, p<.001)$, and four $(M=\$ 28,329$ vs. $\$ 32$, $518, p<.001)$.

The institutional admit rate characteristics were not significantly different $(p>.05)$ for low- and high-SES students, with the exception of the highest academic group, in which high SES students were associated with significantly lower average admit rates than their low-SES counterparts $(M=52.04$ vs. $M=62.69, p<.001$, respectively). There were highly significant $(p$ $<.001)$ differences between high and low-SES students within each academic group in relation to standardized test scores, with the smallest differences found between low- and high-SES students in the second academic group ( $M=1079$ vs. $M=1107, p<.001$, respectively) and the largest differences found in the highest academic group $(M=1176$ vs. $M=1249, p<.001$, respectively). Both first-year retention rates and six-year graduation were associated with highly significant differences $(p<.001)$ between high- and low-SES student in each academic band, with spreads ranging from 4 to 10 percentage points when comparing low- and high-SES students in each of the academic quartiles.

In relation to expenditures and applicant choice sets, high-SES students in the fourth academic group applied to schools with significantly higher fully-loaded costs of instruction than 
their low-SES academic counterparts $(M=\$ 23,068$ vs. $M=\$ 15,959, p<.001$ respectively); no significant differences $(p>.05)$ were found among the other groups. Finally, the endowment expenditures per FTE were consistent with expenditures related to the fully loaded cost of instruction, with high-SES students in the top academic band applying to schools with significantly higher average endowments per FTE than low-SES schools $(M=\$ 62,562$ vs. $M=$ $\$ 39,338, p<.001$, respectively). While this pattern was reversed in the third academic grouping, it was not a highly significant $(p>.05)$ effect.

In turning to the admitted school choice sets, the ANOVA results revealed similar findings as the applied analysis, with significant $(p<.001)$ between-group differences found across each of the institutional characteristics. Table 3 provides information pertaining to the Ftest statistics associated with each of the ANOVAs. In examining the Tukey post-hoc results, significant differences in relation to the number of schools that a student was admitted to were only found among low- and high-SES students in the third academic group $(M=2.33$ and $M=$ $3.01, p<.001$, respectively), whereas the applicant results also revealed significant differences in the fourth academic group. In the inclusive selectivity category, low- and high-SES students in the first and second academic quartiles were associated with significant mean differences $(M=$ $34.2 \%$ and $M=12.8 \%, p<.001$ and $M=12.8 \%$ and $M=5.2 \%, p<.05$, respectively), which was similar to the applicant model. The results of the moderate selectivity category were similar to the applicant results with the exception of significant differences found between low- and highSES students in the lowest academic band $(M=50.9 \%$ vs. $M=65.5 \%, p<.01$, respectively). Additionally, in the high-selectivity category, the significant difference uncovered in the applicant stage between low- and high-SES students in the lowest academic band was not found 
when examining the admitted school choice sets $(M=5.9 \%$ vs. $M=16.4 \%, p>.05$, respectively).

\section{$<<$ INSERT TABLE 3 HERE>>}

While the public and private differences between low- and high-SES students in the admitted choice sets were similar to the applicant choice sets, smaller differences between lowand high-SES students in the second academic group were uncovered compared to the applicant results $(M=80.6 \%$ and $M=69.9 \%, p<.05$ and $M=19.1 \%$ and $M=29.8 \%, p<.05$, respectively). Across all other metrics, the significance patterns for low- and high-SES students across different academic bands remained similar to the applicant choice sets.

Table 4 provides ANOVA results for the enrollment destinations of the students in the analytic sample. Similar to the earlier analyses performed on the applicant and admitted choice sets, the F-tests revealed highly significant $(p<.001)$ between-group differences across all of the institutional characteristics. When comparing differences between low- and high-SES students in each academic group, high-SES students enrolled in schools with significantly higher $(p<.001)$ costs of attendance, standardized test scores, retention rates, and graduation rates compared to their low-SES counterparts with two exceptions: no significant differences $(p>.05)$ were found in the first academic group in relation to the cost of attendance and the second academic group in relation to standardized test scores;. Significant differences in admit rates, however, were only found among high- and low-SES in the top academic band $(M=52.96 \%$ vs. $M=61.12 \%, p<$ .001 , respectively). Similarly, significant expenditures differences were only found among highand low-SES students in the top academic band in relation to the fully-loaded cost of attendance $(M=\$ 21,944$ vs. $M=\$ 17,003, p<.001$, respectively). 


\section{Enrollment Propensities}

In addressing the second research question, I investigated differences in the probabilities of atteding different categories of selectivity through multivariate modeling techniques. In doing so, I used a multinomial logistic regression with the associated PR function in STATA to determine the probability of a student attending an inclusive, moderate-, or high-selectivity. As shown in Table 5, the results of the analysis are displayed as cumulative probabilities (i.e., the probabilities sum to 100 across each academic and SES band) and include the $95 \%$ confidence intervals. This technique is particularly useful in identifying significant differences across groups as values that fall outside of a particular confidence interval are considered significant at the $95 \%$ confidence level $(p<.05)$.

Perhaps the most striking finding relates to the difference uncovered among low- and high-SES students in the highest academic grouping. Despite having the same academic qualifications of high-SES students, low-SES students demonstrate a significantly lower probability of attending a highly selective school than their high-SES counterparts (63.8\% vs. $83.5 \%, p<.05)$. These differences remain significant throughout the high-selectivity category, with statistically similar results $(p<.05)$ found among high- and low-SES students when comparing a lower and higher academic grouping, respectively. When examining the inclusive category, the opposite trend occurs, with low-SES students associated with significantly higher $(p<.05)$ probabilities of attending an inclusive school compared to their high-SES academic counterparts, particularly in the lowest academic groupings.

\section{<<INSERT TABLE 5 HERE >>}

When looking across different academic groups, the cumulative probabilities are also quite telling. Despite the marginal performance of students in the lowest academic band, high- 
SES students have over a $90 \%$ probability of attending a moderate or highly selective school compared to only a $65 \%$ probability for low-SES students. While these probabilities improve in the second academic group, low-SES students still have a 14\% lower probability of attending a moderate or highly selective school compared to their high-SES counterparts. Finally, even when examining students in the top half of the academic distribution, low-SES students are significantly more likely to attend moderately selective schools compared to their high-SES counterparts in academic group $3(55.5 \%$ vs. $34.2 \%, p<.05)$ and academic group 4 (35.4\% vs. $16.0 \%, p<.05)$.

\section{DISCUSSION}

In this study, I examined differences in the institutional characteristics of students' choice sets and enrollment destinations, taking into account their socioeconomic status and level of academic preparation. In addition, I investigated whether there were significant differences in the probabilities of low- and high-SES student enrolling in an inclusive, moderate-, or highselectivity college, controlling for their level of academic preparation and other demographic covariates. Overall, the results demonstrate the pervasiveness of inequality in the college choice decisions of low- and high-SES students and the continued stratification of opportunity for students based on their family background.

While the majority of studies examining college access focus on the initial enrollment destinations of students, typically within two- and four-year tracks (Engberg \& Wolniak, 2010; Perna \& Titus, 2005), few studies have taken a step back to examine differences in the choice sets of students at both the application and admitted stage of the process, particularly for a nationally representative sample of high school students. The findings from this study reveal that low- and high-SES students of the same academic caliber apply to schools that differ in quantity, 
quality, and overall wealth. From the lowest to highest academic quartiles, high-SES students apply to a greater number of schools, which include a proportionally higher number of the country's most selective schools. These trends are repeated across a variety of institutional characteristics related to the overall quality and wealth of applicants' choice sets, including college entrance exams, retention and graduation rates, student expenditures, and endowments. These initial application decisions are replicated in all later stages of the college choice process, creating an indelible pattern of stratification in the educational trajectories of low- and high-SES students.

These results demonstrate that the "undermatching" observed in the enrollment decisions of low-income students (Bastedo \& Jaquette, 2011; Bowen et al., 2009) begins much earlier and that low-SES students are foreclosing on qualitatively better educational options at the earliest stages of the college choice process. The proportional enrollment gaps among low- and high-SES students in the highest academic quartile represent, perhaps, the most startling illustration of educational stratification in American society. Students in the highest academic quartile are undoubtedly academically qualified to attend the most competitive and elite colleges in the nation by any comparative standard, and yet, close to $40 \%$ of low-SES students in this group chose to attend a college that is markedly less competitive based on their grades and standardized test scores. These decisions to attend less selective institutions translate into diminished lifetime earnings, more formidable challenges in relation to college completion, and lower chances of earning a graduate degree (Bowen et al., 2009; Bowen \& Bok, 1998; Wyner, Bridgeland, \& DiIulio, 2007).

The findings from the multinomial regressions suggest that the Lucas's (2001) theory of effectively maintained equality is a plausible explanation for the disparate probabilities of 
enrollment found between low- and high-SES students in the high-selectivity classification of schools. Even when examining a group of students who successfully matriculated to a four-year, non-profit college immediately upon graduation, there are significant differences among lowand high-SES students in relation to institutional selectivity, particularly among the most academically prepared students. While access remains a critical social justice issue and postsecondary education is far from universal (Engberg \& Allen, 2011), this study demonstrates that stratification patterns in postsecondary enrollment remain even when comparing students with equivalent academic qualifications. Bastedo and Jacquette (2011) have also shown that despite overall increases in the academic preparation of low-SES students over time, they have been outpaced by even more substantial gains in academic preparation among high-SES students. Thus, low-SES students remain stratified in both their visibility within the highest academic quartile (approximately 3:1 ratio comparing high- to low-SES students) and in their overall chances to attend the nation's most selective schools.

\section{IMPLICATIONS}

There are no easy solutions in curbing the gaps in enrollment propensities between students from the lowest and highest socioeconomic strata. While one might readily point the finger in the direction of either secondary or postsecondary education, both remain at the nexus of the opportunity structure for low-SES students. At the secondary level, the results suggest that more education and triage are needed as students approach the search stage during the sophomore and juniors years of high school. Hossler et al. (1999) discuss the junior year as a time of openness and discovery in relation to the college search process and suggest that both teachers and counselors may play an important role in helping students determine which schools to consider in their choice sets. Too few counselors, however, have received specific education 
related to the college choice process, and counselor-to-student ratios remain too high in many of the nation's poorest school districts (McDonough, 2005). Thus, curricular efforts are needed that expand school counseling programs to include a focus on the college choice process alongside policy efforts that support increased funding for college-specific counselors. Such efforts are best achieved when supported by district and state policies that show strong support for college enrollment (Perna et al., 2008).

College and universities also play a critical role in leveling the playing field for lowincome students. More effort is needed in recruiting students from lower socioeconomic backgrounds, particularly those who are admitted to a highly selective school. Research has shown that low-income students who meet with a college representative (Engberg \& Allen, 2011) or receive financial information (Cabrera \& La Nasa, 2001) are significantly more likely to attend college (Engberg \& Allen, 2011), yet admission counselors are more likely to establish relationships with high schools in high-income neighborhoods (Wolniak \& Engberg, 2007). Given the inordinate amount of money that colleges spend in recruiting student athletes, similar efforts are needed to ensure that academically qualified low-SES students are attending the nation's most selective schools at similar rates as their high-SES counterparts. This may be overly idealistic, akin to thinking if only the government would divert a fraction of the money spent on the military to educational reform, but low-SES students have been "running in place" for decades (Bastedo et al., 2011), warranting a reconsideration of how funds are allocated in the college recruitment process.

Finally, more attention is needed at the federal level to address enrollment disparities among low- and high-SES students. The Pell Institute (2011) has recommended several changes, including reconsideration of how Title I funds are distributed to ensure that these funds are 
directed toward the neediest schools and the protection and continuation of Pell grants and Federal Trio programs. All of these initiatives provide low-income students with supplemental support to help increase their likelihood of enrolling in a postsecondary institution. President Obama also recently announced a "Pay As You Earn” program (White House, 2011), allowing greater loan forgiveness and creating a more progressive system of repayment. While these inducements are geared toward graduates, the changes may tip the scales when low-SES students consider the cost-benefit analysis of attending a selective college, although such an effect is contingent on students receiving adequate information about the details of loan repayment. Only through joint efforts at both the secondary and postsecondary level, with the support of state and federal policymakers, can significant strides be made in suppressing the persistent patterns of stratification that mark the American educational system.

\section{REFERENCES}

ACT (2011). ACT-SAT concordance. Retrieved from http://www.act.org/aap/concordance/

Alon, S., \& Tienda, M. (2005). Assessing the "mismatch" hypothesis: Differences in college graduation rates by institutional selectivity. Sociology of Education, 78(4), 294-315.

Arum, R., Gamoran, A., \& Shavit, Y. (2007). More inclusion than diversion: Expansion, differentiation, and market structure in higher education. In Y. Shavit, R. Arum, \& A. Gamoran (Eds.) Expansion, differentiation and inequality of access to higher education: A comparative study (pp.1-35). Stanford, CA: Stanford University Press.

Bastedo, M. N., \& Jaquette, O. (2011). Running in place: Low-income students and the dynamics of higher education stratification. Educational Evaluation and Policy Analysis, 33(3), 318-339. 
Becker, G. S. (1993). Human capital: A theoretical and empirical analysis with special reference to education ( $3^{\text {rd }}$ Ed.). Chicago, IL: University of Chicago Press.

Bowen, W. G., \& Bok, D. (1998). The shape of the river: Long-term consequences of considering race in college and university admissions. Princeton, NJ: Princeton University Press.

Bowen, W. G., Chingos, M. M., \& McPherson, M. S. (2009). Crossing the finish line: Completing college at America's public universities. Princeton, NJ: Princeton University Press.

Breen, R., \& Jonsson, J. O. (2000). Analyzing educational careers: A multinomial transition model. American Sociological Review, 65(5), 754-772.

Brewer, D. J., Eide, E. R., \& Ehrenberg, R. G. (1999). Does it pay to attend an elite private college? Cross-cohort evidence on the effects of college type on earnings. The Journal of Human Resources, 34(1), 104-123.

Cabrera, A. F., \& La Nasa, S. M. (2001). On the path to college: Three critical tasks facing America's disadvantaged. Research in Higher Education, 42(2), 119-149.

Carnegie Foundation for the Advancement of Teaching (n.d.). Methodology: Undergraduate profile classification. Retrieved from http://classifications.carnegiefoundation.org/methodology/ugrad_profile.php

Carnevale, A. P. (2010, April 1). Access to money and power. New York Times. Retrieved from http://www.nytimes.com/roomfordebate/2010/11/29/does-it-matter-where-you-go-tocollege/lifelong-benefit-access-to-money-and-power

Carnevale, A. P., \& Rose, S. J. (2003). Socioeconomic status, racelethnicity and selective college admissions. New York, NY: The Century Foundation. 
Coleman, J. S. (1988). Social capital in the creation of human capital. American Journal of Sociology, 94(1), S95-S120.

Davis-Kean, P.E. (2005). The Influence of Parent Education and Family Income on Child Achievement: The Indirect Role of Parental Expectations and the Home Environment. Journal of Family Psychology, 19(2), 294-304.

Ellwood, D. T., \& Kane, T. J. (2000). Who is getting a college education? Family background and the growing gaps in enrollment. In S. Danziger \& J. Waldfogel (Eds.), Securing the future: Investing in children from birth to college (pp. 283-324). New York, NY: Russell Sage Foundation.

Engberg, M. E., \& Allen, D.J. (2011). Uncontrolled destinies: Improving opportunity for lowincome students in American higher education. Research in Higher Education, 52(8), 786-807.

Engberg, M. E., \& Wolniak, G. C. (2010). Examining the effects of high school contexts on postsecondary enrollment. Research in Higher Education, 51(2), 132-153.

Fitzgerald, B. K., \& Delaney, J. A. (2002). Educational opportunity in America. In D. E. Heller (Ed.), Condition of access: Higher education for lower income students (pp. 3-24). Westport, CT: Praeger.

Grodsky, E. (2007). Compensatory sponsorship in higher education. American Journal of Sociology, 112(6), 1662-1712.

Haycock, K., Lynch, M., \& Engle, J. (2010). Opportunity adrift: Our flagship universities are straying from their public mission. Washington, DC: The Education Trust.

Hill, L. D. (2008). School strategies and the "college-linking" process: Reconsidering the effects of high schools on college enrollment. Sociology of Education, 81(1), 53-76. 
Hossler, D., \& Gallagher, K. S. (1987). Studying student college choice: A three-phase model and the implications for policymakers. College and University, 62(3), 207-221.

Hossler, D., Schmit, J. L., \& Vesper, N. (1999). Going to college: How social, economic, and educational factors influence the decisions students make. Baltimore, MD: Johns Hopkins University Press.

Karen, D. (1990). Toward a political-organizational model of gatekeeping: The case of elite colleges. Sociology of Education, 63(4), 227-240.

Leslie, L. L., \& Brinkman, P. T. (1987). Student price response in higher education: The student demand studies. The Journal of Higher Education, 58(2), 181-204.

Lin, N. (1999). Social networks and status attainment. Annual Review of Sociology, 25, 467-487.

Lucas, S. (2001). Effectively maintained inequality: Education transitions, track mobility, and social background effects. American Journal of Sociology, 106(6), 1642-1690.

McDonough, P. M. (1994). Buying and selling higher education: The social construction of the college applicant. The Journal of Higher Education, 65(4), 427-446.

McDonough, P. M. (1997). Choosing colleges: How social class and schools structure opportunity. Albany, NY: State University of New York Press.

McDonough, P. M. (2005). Counseling and college counseling in America's high schools. In D.

A. Hawkins \& J. Lautz (Eds.), State of college admission (pp. 107-121). Washington, DC: National Association for College Admission Counseling.

Müller, W., \& Karle, W. (1993), Social selection in educational systems in Europe. European Sociological Review, 9(1), 1-23. 
National Center for Educational Statistics. (2007). Educational longitudinal study of 2002 (ELS: 2002); A first look the initial postsecondary experiences of the high school sophomore class of 2002. Washington, DC: U.S. Department of Education.

Paulsen, M. B. (2001). The economics of human capital and investment in higher education. In M. B. Paulsen and J. C. Smart (Eds.), The finance of higher education: Theory, research, policy, and practice (pp. 55-94). New York, NY: Agathon Press.

Pell Institute (2011). Developing 20/20 vision on the 2020 degree attainment goal. The threat of income-based inequality in education. Washington, DC: Pell Institute. Retrieved from http://www.pellinstitute.org/publications Developing_2020_Vision_May_2011.shtml

Pérez, P. A., \& McDonough, P. M. (2008). Understanding Latina and Latino college choice: A social capital and chain migration analysis. Journal of Hispanic Higher Education, 7(3), 249-265.

Perna, L. W. (2006). Studying college access and choice: A proposed conceptual model, In J. C. Smart (Eds.), Higher education: Handbook of theory and research (Vol. XXI, pp. 99157). New York, NY: Agathon Press.

Perna, L. W., Rowan-Kenyon, H. T., Thomas, S. L., Bell, A., Anderson, R., \& Li, C. (2008). The role of college counseling in shaping college opportunity: Variations across high schools. Review of Higher Education, 31(2), 131-159.

Perna, L. W., \& Titus, M. A. (2005). The relationship between parental involvement as social capital and college enrollment: An examination of racial/ethnic group differences. The Journal of Higher Education, 76(5), 485-518.

Raftery, A. E., \& Hout, M. (1993). Maximally maintained inequality: Expansion, reform, and opportunity in Irish education, 1921-75. Sociology of Education, 66(1), 41-62. 
Rosenbaum, J. E. (1978). The structure of opportunity in school. Social Forces, 57(1), 236-256.

Rosenbaum, J. E., Miller, S. R., \& Krei, M. S. (1996). Gatekeeping in an era of more open gates: high school counselors' views of their influence on students' college plans. American Journal of Education, 104(4), 257-279.

Schafer, J. L. (1997). Analysis of incomplete multivariate data. London, England: Chapman and Hall.

Shavit, Y., \& Blossfeld, H.-P. (1993). Persistent inequality: Changing educational attainment in thirteen countries. Boulder, CO: Westview Press.

Thomas, S. L. (2000). Deferred costs and economic returns and to college major, quality, and performance. Research in Higher Education, 41(3), 281-313.

Thomas, S. L., \& Perna, L. W. (2004). The opportunity agenda: A reexamination of postsecondary reward and opportunity. In J. C. Smart (Eds.), Higher education: Handbook of theory and research. (Vol. XIX, pp. 43-84). Boston, MA: Kluwer Academic.

Turner, R. H. (1960). Sponsored and contest mobility and the school system. American Sociological Review, 25(6), 855-867.

White House (2011, October 25). We can't wait: Obama administration to lower student loan payments for millions of borrowers. Retrieved from http://www.whitehouse.gov/thepress-office/2011/10/25/we-cant-wait-obama-administration-lower-student-loanpayments-millions-b

Wolniak, G. C., \& Engberg, M. E. (2007). The effects of high school feeder networks on college enrollment. Review of Higher Education, 31(1), 27-53. 
Wyner, J. S., Bridgeland, J. M., \& Dilulio, J. J. (2007). Achievementrap: How America is failing millions of high-achieving students from lower-income families. Landsdowne, VA: Jack Kent Cooke Foundation. 
Table 1. Mean Component Values by Academic Profile Group Academic Profile

\begin{tabular}{cccc} 
Group & AP/IB & GPA & SAT $^{*}$ \\
\hline 1.00 & .21 & 2.53 & 856 \\
2.00 & .63 & 3.07 & 1020 \\
3.00 & 1.53 & 3.38 & 1135 \\
4.00 & 4.17 & 3.60 & 1298 \\
\hline
\end{tabular}

* Represents the higher value of SAT or converted ACT scores 
Table 2. Mean Applied Choice Set Characteristics by Academic and SES Groups*

\begin{tabular}{|c|c|c|c|c|c|c|c|c|}
\hline $\begin{array}{c}\text { Academic } \\
\text { Group }\end{array}$ & $\begin{array}{l}\text { SES } \\
\text { Group }\end{array}$ & $\begin{array}{l}\text { Number } \\
\text { Schools } \\
\text { Applied }\end{array}$ & $\begin{array}{l}\text { Percent } \\
\text { Inclusive } \\
\text { Schools }\end{array}$ & $\begin{array}{l}\text { Percent } \\
\text { Moderate } \\
\text { Selective } \\
\text { Schools** }\end{array}$ & $\begin{array}{l}\text { Percent } \\
\text { High } \\
\text { Selective } \\
\text { Schools** }\end{array}$ & $\begin{array}{l}\text { Percent } \\
\text { Public }\end{array}$ & $\begin{array}{l}\text { Percent } \\
\text { Private }\end{array}$ & $\begin{array}{l}\text { Cost to } \\
\text { Attend }\end{array}$ \\
\hline 1.00 & Low & 3.10 & $28.5 \%$ & $47.6 \%$ & $8.8 \%$ & $79.4 \%$ & $18.7 \%$ & 22,574 \\
\hline (Low) & High & 3.54 & $10.8 \%$ & $54.7 \%$ & $22.0 \%$ & $80.1 \%$ & $19.0 \%$ & 24,143 \\
\hline \multirow[t]{2}{*}{2.00} & Low & 2.96 & $11.0 \%$ & $56.0 \%$ & $20.7 \%$ & $83.2 \%$ & $16.5 \%$ & 23,906 \\
\hline & High & 3.32 & $3.7 \%$ & $52.1 \%$ & $36.4 \%$ & $70.0 \%$ & $29.1 \%$ & 26,006 \\
\hline \multirow[t]{2}{*}{3.00} & Low & 2.96 & $7.3 \%$ & $52.0 \%$ & $33.0 \%$ & $72.0 \%$ & $28.0 \%$ & 25,934 \\
\hline & High & 3.98 & $3.6 \%$ & $37.9 \%$ & $53.1 \%$ & $64.0 \%$ & $35.5 \%$ & 27,944 \\
\hline \multirow{3}{*}{$\begin{array}{c}4.00 \\
\text { (High) }\end{array}$} & Low & 3.87 & $3.9 \%$ & $35.7 \%$ & $52.0 \%$ & $65.0 \%$ & $34.8 \%$ & 28,329 \\
\hline & High & 4.48 & $1.3 \%$ & $16.8 \%$ & $78.4 \%$ & $47.9 \%$ & $51.9 \%$ & 32,518 \\
\hline & $\begin{array}{l}\text { F- } \\
\text { test }^{* * * * *}\end{array}$ & 22.01 & 68.04 & 54.03 & 187.94 & 31.78 & 34.30 & 110.46 \\
\hline
\end{tabular}

"Based on a weighted sample of 1,193,611 students in the restricted ELS dataset who continuously enrolled in an inclusive, moderate, or high selectivity four-year non-profit institution; italics represents non-significant mean differences between low and high SES within a particular academic band based on Tukey post-hoc tests

***Based on Carnegie classification of school selectivity

****Based on out-of-state tuition in 2004-2005 academic year

${ }^{* * * *}$ All F-test differences were significant at $\mathrm{p}<.001$ level

Table 2 (cont). Mean Applied Choice Set Characteristics by Academic and SES Groups*

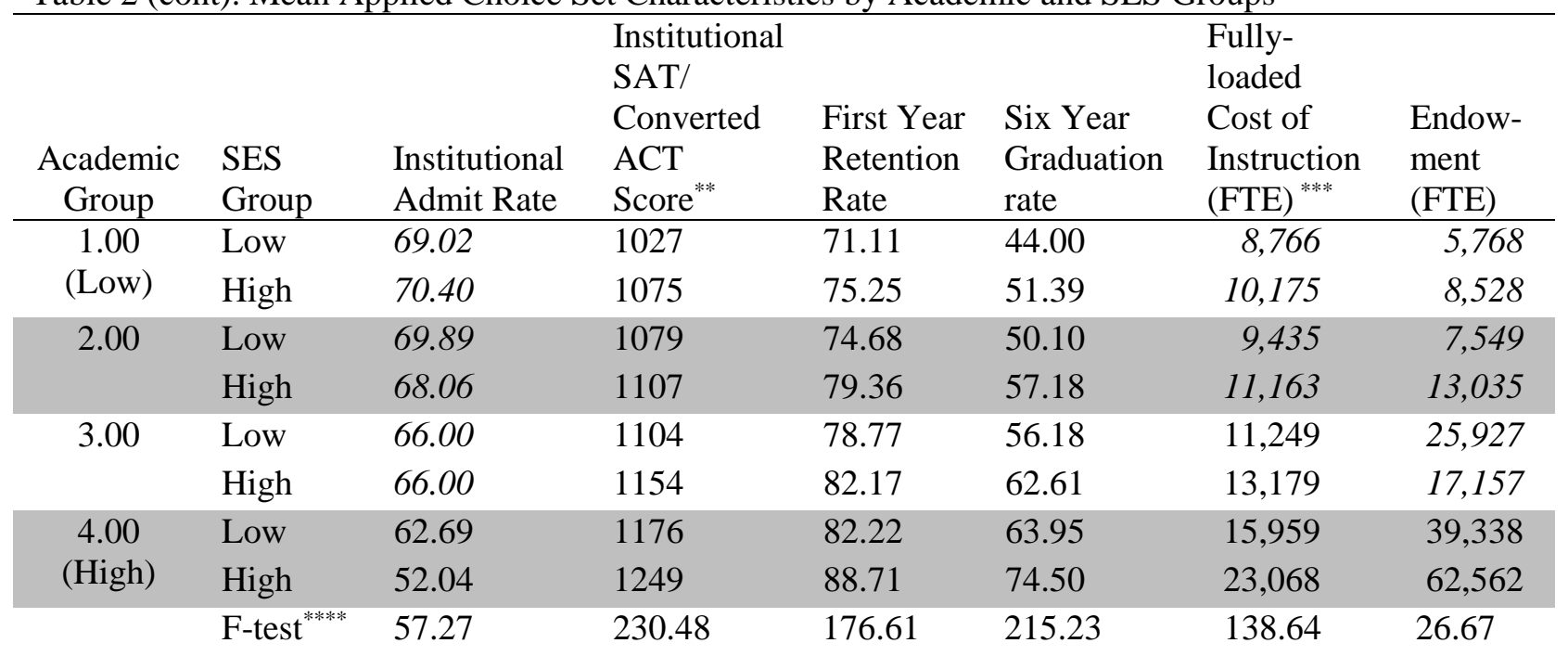

"Based on a weighted sample of 1,193,611 students in the restricted ELS dataset who continuously enrolled in an inclusive, moderate-, or high-selectivity, four-year, non-profit institution; italics represents non-significant mean differences between low- and high-SES within a particular academic band based on Tukey post-hoc tests

**Based on weighted proportion of SAT and ACT test takers on a particular campus

${ }^{* * * *}$ Based on instructional, academic support, and student services expenditures per FTE

${ }^{* * * *}$ All F-test differences were significant at $\mathrm{p}<.001$ level 
Table 3. Mean Admitted Choice Set Characteristics by Academic and SES Groups*

\begin{tabular}{|c|c|c|c|c|c|c|c|c|}
\hline \multirow{3}{*}{$\begin{array}{c}\text { Academic } \\
\text { Group }\end{array}$} & & Number & Percent & $\begin{array}{l}\text { Percent } \\
\text { Moderate }\end{array}$ & $\begin{array}{l}\text { Percent } \\
\text { High }\end{array}$ & & & \\
\hline & SES & Schools & Inclusive & Selective & Selective & Percent & Percent & Cost to \\
\hline & Group & Admitted & Schools ${ }^{* *}$ & Schools** & Schools $^{* *}$ & Public & Private & Attend $^{* * * *}$ \\
\hline \multirow{2}{*}{$\begin{array}{c}1.00 \\
\text { (Low) }\end{array}$} & Low & 2.13 & $34.2 \%$ & $50.9 \%$ & $5.9 \%$ & $78.9 \%$ & $19.6 \%$ & 22,297 \\
\hline & High & 2.32 & $12.8 \%$ & $65.6 \%$ & $16.4 \%$ & $76.9 \%$ & $22.4 \%$ & 23,864 \\
\hline \multirow[t]{2}{*}{2.00} & Low & 2.26 & $12.8 \%$ & $62.9 \%$ & $17.9 \%$ & $80.6 \%$ & $19.1 \%$ & 23,425 \\
\hline & High & 2.59 & $5.2 \%$ & $60.2 \%$ & $32.0 \%$ & $69.9 \%$ & $29.8 \%$ & 25,680 \\
\hline \multirow[t]{2}{*}{3.00} & Low & 2.33 & $7.4 \%$ & $57.9 \%$ & $30.9 \%$ & $72.6 \%$ & $27.4 \%$ & 25,675 \\
\hline & High & 3.01 & $3.7 \%$ & $42.0 \%$ & $52.7 \%$ & $64.5 \%$ & $35.4 \%$ & 27,565 \\
\hline \multirow{3}{*}{$\begin{array}{c}4.00 \\
\text { (High) }\end{array}$} & Low & 3.06 & $4.6 \%$ & $39.2 \%$ & $51.9 \%$ & $65.8 \%$ & $34.0 \%$ & 27,862 \\
\hline & High & 3.25 & $1.2 \%$ & $18.5 \%$ & $78.5 \%$ & $51.8 \%$ & $48.1 \%$ & 31,770 \\
\hline & $\begin{array}{l}\text { F- } \\
\text { test }^{* * * * *}\end{array}$ & 21.97 & 72.26 & 53.57 & 178.91 & 18.22 & 19.48 & 103.02 \\
\hline
\end{tabular}

"Based on a weighted sample of 1,193,611 students in the restricted ELS dataset who continuously enrolled in an inclusive, moderate, or high selectivity four-year non-profit institution; italics represents non-significant mean differences between low and high SES within a particular academic band based on Tukey post-hoc tests

${ }^{* *}$ Based on Carnegie classification of school selectivity;

***** Based on out-of-state tuition in 2004-2005 academic year

${ }^{* * * *}$ All F-test differences were significant at $\mathrm{p}<.001$ level

Table 3 (cont.). Mean Admitted Choice Set Characteristics by Academic and SES Groups*

\begin{tabular}{|c|c|c|c|c|c|c|c|}
\hline $\begin{array}{l}\text { Academic } \\
\text { Group }\end{array}$ & $\begin{array}{l}\text { SES } \\
\text { Group }\end{array}$ & $\begin{array}{l}\text { Institutional } \\
\text { Admit Rate }\end{array}$ & $\begin{array}{l}\text { Institutional } \\
\text { SAT/ } \\
\text { Converted } \\
\text { ACT } \\
\text { Score }\end{array}$ & $\begin{array}{l}\text { First Year } \\
\text { Retention } \\
\text { Rate }\end{array}$ & $\begin{array}{l}\text { Six Year } \\
\text { Graduation } \\
\text { Rate }\end{array}$ & $\begin{array}{l}\text { Fully- } \\
\text { loaded } \\
\text { Cost of } \\
\text { Instruction } \\
(\text { FTE) })^{* * * *}\end{array}$ & $\begin{array}{l}\text { Endow- } \\
\text { ment } \\
\text { (FTE) }\end{array}$ \\
\hline \multirow{2}{*}{$\begin{array}{c}1.00 \\
(\mathrm{Low})\end{array}$} & Low & 69.89 & 1015 & 70.66 & 42.33 & 8,741 & 6,555 \\
\hline & High & 71.59 & 1050 & 74.69 & 49.14 & 9,301 & 8,084 \\
\hline \multirow[t]{2}{*}{2.00} & Low & 71.47 & 1063 & 74.65 & 48.85 & 9,062 & 7,777 \\
\hline & High & 69.40 & 1093 & 79.05 & 55.40 & 10,696 & 12,631 \\
\hline \multirow[t]{2}{*}{3.00} & Low & 67.41 & 1092 & 78.62 & 54.64 & 10,802 & 20,719 \\
\hline & High & 68.22 & 1143 & 82.32 & 61.35 & 12,616 & 18,999 \\
\hline \multirow{3}{*}{$\begin{array}{c}4.00 \\
\text { (High) }\end{array}$} & Low & 64.83 & 1162 & 82.69 & 63.02 & 14,354 & 28,585 \\
\hline & High & 56.40 & 1229 & 88.26 & 72.46 & 19,927 & 55,842 \\
\hline & F-test ${ }^{* * * *}$ & 39.12 & 226.60 & 175.59 & 207.24 & 118.54 & 28.80 \\
\hline
\end{tabular}

"Based on a weighted sample of 1,193,611 students in the restricted ELS dataset who continuously enrolled in an inclusive, moderate, or high selectivity four-year non-profit institution; italics represents non-significant mean differences between low and high SES within a particular academic band based on Tukey post-hoc tests

**Based on weighted proportion of SAT and ACT test takers on a particular campus

${ }^{* * * *}$ Based on instructional, academic support, and student services expenditures per FTE

${ }^{* * * *}$ All F-test differences were significant at $\mathrm{p}<.001$ level 
Table 4. Mean Enrollment Characteristics by Academic and SES Groups*

\begin{tabular}{|c|c|c|c|c|c|c|c|c|}
\hline $\begin{array}{c}\text { Academic } \\
\text { Group }\end{array}$ & $\begin{array}{l}\text { SES } \\
\text { Group }\end{array}$ & $\begin{array}{l}\text { Cost to } \\
\text { Attend }\end{array}$ & $\begin{array}{l}\text { Institu- } \\
\text { tional } \\
\text { Admit } \\
\text { Rate }\end{array}$ & $\begin{array}{l}\text { Institu- } \\
\text { tional } \\
\text { SAT/ } \\
\text { Converted } \\
\text { ACT } \\
\text { Score }\end{array}$ & $\begin{array}{l}\text { First } \\
\text { Year } \\
\text { Reten- } \\
\text { tion } \\
\text { Rate }\end{array}$ & $\begin{array}{l}\text { Six } \\
\text { Year } \\
\text { Gradua- } \\
\text { tion } \\
\text { Rate }\end{array}$ & $\begin{array}{l}\text { Fully- } \\
\text { loaded } \\
\text { Cost of } \\
\text { Instruc- } \\
\text { tion } \\
(\mathrm{FTE})^{* * * *}\end{array}$ & $\begin{array}{l}\text { Endow- } \\
\text { ment } \\
\text { (FTE) }\end{array}$ \\
\hline \multirow{2}{*}{$\begin{array}{c}1.00 \\
\text { (Low) }\end{array}$} & Low & 22,220 & 70.04 & 1003 & 70.78 & 41.71 & 8,943 & 8,493 \\
\hline & High & 23,591 & 72.43 & 1048 & 76.00 & 49.53 & 9,519 & 10,247 \\
\hline \multirow[t]{2}{*}{2.00} & Low & 23,609 & 71.08 & 1067 & 75.86 & 48.84 & 9,508 & 9,844 \\
\hline & High & 25,751 & 69.21 & 1089 & 79.35 & 56.49 & 10,647 & 17,657 \\
\hline \multirow[t]{2}{*}{3.00} & Low & 25,727 & 67.27 & 1096 & 79.42 & 55.21 & 11,017 & 26,400 \\
\hline & High & 27,557 & 66.44 & 1151 & 83.15 & 62.55 & 13,068 & 33,379 \\
\hline \multirow{3}{*}{$\begin{array}{c}4.00 \\
\text { (High) }\end{array}$} & Low & 28,304 & 61.12 & 1174 & 84.17 & 65.50 & 17,003 & 95,570 \\
\hline & High & 32,115 & 52.96 & 1247 & 89.53 & 74.61 & 21,944 & 120,831 \\
\hline & F-test ${ }^{* * * * * *}$ & 83.38 & 39.42 & 192.05 & 143.05 & 174.66 & 89.82 & 39.60 \\
\hline
\end{tabular}

"Based on a weighted sample of 1,193,611 students in the restricted ELS dataset who continuously enrolled in an inclusive, moderate-, or high-selectivity, four-year, non-profit institution; italics represents non-significant mean differences between low- and high-SES within a particular academic band based on Tukey post-hoc tests

**Based on out-of-state tuition in 2004-2005 academic year

${ }^{* * * *}$ Based on weighted proportion of SAT and ACT test takers on a particular campus

${ }^{* * * *}$ Based on instructional, academic support, and student services expenditures per FTE

${ }^{* * * * *}$ All F-test differences were significant at $\mathrm{p}<.001$ level

Table 5. Predicted Probabilities of Four-Year Enrollment Selectivity by Academic and Socioeconomic Classifications*

\begin{tabular}{|c|c|c|c|c|c|c|c|c|c|c|}
\hline \multirow{2}{*}{$\begin{array}{l}\text { Academic } \\
\text { Group }\end{array}$} & \multirow[b]{2}{*}{$\begin{array}{l}\text { SES } \\
\text { Group }\end{array}$} & \multicolumn{3}{|c|}{$\begin{array}{c}\text { Inclusive Selectivity } \\
\text { 95\% Confidence Interval }\end{array}$} & \multicolumn{3}{|c|}{$\begin{array}{l}\text { Moderate Selectivity } \\
\text { 95\% Confidence Interval }\end{array}$} & \multicolumn{3}{|c|}{$\begin{array}{c}\text { High Selectivity } \\
\text { 95\% Confidence Interval }\end{array}$} \\
\hline & & Low & Est. & High & Low & Est. & High & Low & Est. & High \\
\hline \multirow{2}{*}{$\begin{array}{l}1.00 \\
(\text { Low })\end{array}$} & Low & 31.6 & 35.8 & 40.1 & 54.1 & 58.3 & 62.4 & 4.3 & 5.9 & 7.5 \\
\hline & High & 3.9 & 8.1 & 12.3 & 68.3 & 73.4 & 79.4 & 13.8 & 18.1 & 22.4 \\
\hline \multirow[t]{2}{*}{2.00} & Low & 15.0 & 17.6 & 20.1 & 62.2 & 65.3 & 68.3 & 14.7 & 17.2 & 19.6 \\
\hline & High & 2.5 & 4.1 & 5.8 & 52.8 & 57.1 & 61.4 & 34.5 & 38.8 & 43.0 \\
\hline \multirow[t]{2}{*}{3.00} & Low & 4.5 & 6.5 & 8.5 & 51.2 & 55.5 & 59.3 & 34.2 & 38.0 & 41.7 \\
\hline & High & 0.8 & 1.6 & 2.5 & 31.3 & 34.2 & 37.0 & 61.3 & 64.2 & 67.1 \\
\hline \multirow{2}{*}{$\begin{array}{l}4.00 \\
\text { (High) }\end{array}$} & Low & 0.9 & 1.8 & 2.8 & 29.5 & 35.4 & 41.3 & 56.8 & 62.8 & 68.8 \\
\hline & High & 0.1 & 0.5 & 0.9 & 13.4 & 16.0 & 18.7 & 80.1 & 83.5 & 86.1 \\
\hline
\end{tabular}

"Based on a weighted sample of 1,193,611 students in the restricted ELS dataset who continuously enrolled in an inclusive, moderate-, or high-selectivity, four-year, non-profit institution. Probabilities derived from multinomial logistic regression models run within each socioeconomic classification using the "prvalue" function in STATA for each academic level, controlling for demographic covariates 
${ }^{1}$ The weighted sample was derived from the F1F2WT panel weight contained in the restricted ELS data set. Based on the multi-stage design of the ELS, this weight applies to those students who were seniors in high school in 2004 who participated in the second follow-up in 2006. For purposes of analysis, a normalized weighting procedure was used based on the subpopulation command available in the complex survey module of SPSS v.19.

${ }^{2}$ The Carnegie Foundation now uses a different classification system that includes information pertaining to both size and transfer rates; the categories of inclusive, moderate, and high selectivity correspond to the current classification categories of inclusive, selective, and more selective schools (Carnegie Foundation for the Advancement of Teaching; n.d.).

${ }^{3}$ Information on endowment was only available for the 2006 academic year.

${ }^{4}$ Cost of attendance includes tuition, fees, room, board, and other college-related expenses. Because the ELS data set does not include residency information for individual respondents, it was not possible to determine whether a particular student would be eligible for in- or out-of-state tuition.

${ }^{5}$ The study by Bastedo and Jacquette (2011) provides a recent example of a stratification study that utilized the SES composite index; see also Cabrera and La Nasa (2001).

${ }^{6}$ Given the analytic sample included students enrolled in a four-year institution, missing data on the academic profile components was generally small (less than 6\%). I used a multiple imputation method (Markov chain Monte Carlo iterative method; Schafer 1997) to replace missing data before computing the academic index.

${ }^{7}$ The logistic regression initially tested the effects of mathematics and science preparation and the ELS standardized tests of Math and English. These variables shared a non-significant relationship with the likelihood of attending a highly selective college.

${ }^{8}$ All of the schools were listed in a transactional format and later analyses required a flat file format in which choice set characteristics were associated with one unique identifier.

${ }^{9}$ This was in keeping with Lucas's (2001) modeling techniques.

${ }^{10}$ Alternative models included a number of variables used in earlier college choice models, particularly variables related to economic, human, social, and cultural capital (see Engberg \& Wolniak, 2010). 